\title{
Women's Representation in the Post-Soviet Space: Latvia and Lithuania
}

Avery Beam, Southwestern University, Texas

\section{Abstract}

Using a most-similar case design to compare Latvia and Lithuania, this study examines the role electoral systems play in affecting greater representation of women in postSoviet democracies. After the country's most recent election, Latvia demonstrated a higher percentage of women in its parliament than Lithuania. Interestingly, despite having higher descriptive representation, Latvia has no quotas or women's organisations/caucuses while Lithuania implements voluntary quotas and has a prevalent women's caucus. This study advances an institutional argument, hypothesising that the Latvian parliament's higher percentage of women can be attributed to its proportional representation electoral system. Lithuania has a mixed system that has favoured a majoritarian pole. This, in turn, has adversely affected women's electoral success. In many ways, women's substantive representation in Latvia and Lithuania is only marginally different. However, regarding the sheer number of women in parliament, the difference between Lithuania and Latvia proves relatively marked. The Latvian and Lithuanian cases demonstrate that proportional representation electoral systems are more favourable to women candidates than mixed systems, even in the absence of quotas and a women's movement, and particularly in the context of post-Soviet democracies.

Keywords: Women's representation, descriptive representation, electoral systems, post-Soviet democracies, institutionalism, proportional representation system, Eastern European democratic development, post-communist democracies

\section{Introduction}

As post-communist countries with relatively new democratic systems of government, Latvia and Lithuania have struggled to overcome the legacy of Soviet ideological and political structures that have inhibited the success of minority candidates, specifically women candidates. After its 2018 parliamentary election, Latvia demonstrated a much higher percentage of women in its parliament (31 per cent) than Lithuania (21 per 
Reinvention: an International Journal of Undergraduate Research 13:1 (2020) cent, at the time). Following Lithuania's most recent parliamentary election in 2019, its parliament's percentage of women shifted to 24 per cent - still leaving a statistically significant margin between that of Latvia's. Interestingly, despite having higher descriptive representation, Latvia has no quotas or women's organisations while Lithuania implements voluntary quotas and has a prevalent women's caucus. This gender disparity between Latvia and Lithuania's respective parliaments begs the question: why does Latvia have higher descriptive representation for women than Lithuania? I argue that the Latvian parliament's higher percentage of women can be attributed to its proportional representation electoral system. Lithuania has a mixed system that has favoured a majoritarian tier that, in turn, has adversely affected women's electoral success. In many ways, women's substantive representation in Latvia and Lithuania is only marginally different. However, in regard to the sheer number of women in parliament, the difference between the countries proves relatively marked. The Latvian and Lithuanian cases demonstrate that proportional representation electoral systems are more favourable to women candidates than mixed systems, even in the absence of quotas and a women's movements, and particularly in the context of post-Soviet democracies. Relatively little research has been done regarding the effects of electoral systems on gender equality in post-Soviet democracies. The Latvian and Lithuanian cases prove especially significant because they confirm a strand of the women and politics literature that posits that electoral systems play a crucial role in advancing gender equality, specifically in post-Soviet, EU enlargement countries that have recently transitioned to democratic, parliamentary systems.

\section{Most-similar cases: Latvia and Lithuania}

This study employs a most-similar case design to compare Latvia and Lithuania and demonstrate that electoral systems are the most significant causal factor affecting the number of women in post-Soviet parliaments. As countries that have struggled to adequately accede to EU standards for equality and promote women candidates in the post-Soviet space, Latvia and Lithuania provide ideal cases to test the electoral systems explanation for women's representation. Latvia and Lithuania's substantial similarities provide analytical leverage so that a large number of historical, political, and ideological factors have less explanatory power when determining the factor that most influences descriptive representation in these countries.

Lithuania and Latvia are culturally similar and have closely linked historical experiences. Both countries gained independence from the Soviet Union in 1991 and 

joined the European Union and NATO in 2004. Their shared communist history has influenced their current political, economic and social development in important ways. After the collapse of communism, these countries underwent a similar transition to democratic regimes and liberal market economies and experienced political and economic instability, raising rates of unemployment and a reform of socialist welfare state (Avdeyeva, 2010, 203). Most crucially, both countries went through a process of accession to the European Union, which established a single standard of policy across the countries (Avdeyeva, 2010, 203). Cowles, Caporaso and Risse argue that the capacity to accede to the EU, 'or countries' ability to adhere to the EU policy standards in different policy areas, depends on the fit between existing national policies and EU requirements' (cited in Avdeyeva, 2010, 207). In other words, countries where domestic policies are closer to EU standards typically have more streamlined, effective adoption and enforcement processes for democratic policies. In her large $\mathrm{N}$ study examining gender equality in EU enlargement countries, Avdeyeva finds that governments are more likely to adopt and implement international standards on gender equality in those countries that were initially better prepared for accession (Avdeyeva, 2010, 207). As the countries are former Soviet states that are deeply entrenched in the legacy of communism politically, economically and even culturally, EU experts accurately considered Latvia and Lithuania less prepared for accession than other states. This, in turn, affected the likelihood of the implementation of gender equality measures in these countries (Avdeyeva, 2010, 208). Effectively, Latvia and Lithuania inherited similar communist legacies and had to go through a major transition to embrace the norms, values and practices of democratic regimes. This is particularly important for capturing the political and social struggles that evolved in post-communist Latvia and Lithuania - specifically a divide around policies related to gender equality.

Latvia and Lithuania both operate under a unicameral parliamentary system and do not implement any compulsory gender quotas on the governmental level. Overall gender equality proves minimal in both countries, especially in terms of women's numbers in elite economic positions and policies that directly benefit women. However, in the workforce, gender equality proves relatively high for Latvia and Lithuania. Employing the Gender Equality Index published by the European Institute for Gender Equality, one can determine the similarities in gender equality across countries a part of the European Union. The Index measures the differences between women and men in key domains of the EU policy framework (e.g. workforce, healthcare), using a scale from 1 (full inequality) to 100 (full equality). In the Gender 
Equality Index 2017, Latvia achieved a score of 57.0 out of 100 (European Institute for Gender Equality 2017, 1). Lithuania achieved a score of 56.8 out of 100 (European Institute for Gender Equality 2017, 1). Lithuania and Latvia rank relatively well in the domain of work, with participation for women scoring the fourth- and fifth-best positions in the EU-28, respectively (European Institute for Gender Equality 2017, 3). Both countries have almost reached the national target (73 per cent) of the Europe 2020 strategy (a ten-year strategy to advance the European Union's economy; EU2020) (European Institute for Gender Equality 2017, 1).

In terms of top economic and leadership positions, women remain largely deficient. Additionally, women in these countries are still expected to care for their families; women assume a double role within the workforce and at home, which complicates their position in the economic sphere (Tripp, 2013, 512). Although a number of women have been elected to powerful political positions - Lithuania's and Latvia's Speaker of the Parliament are both women - their representation is symbolic with no real political power to influence policy (Tripp, 2013, 512). Although Lithuania has proven compliant to EU standards of gender equality and demonstrates higher levels of compliance than most Eastern European states, gender equality policies still prove lacking in most issue areas (e.g. childcare, income; European Institute for Gender Equality, 2017, 3). Even though equal opportunity policy is realised in post-Soviet Lithuanian society, actual changes in society have proven slow (Jurènienė, 2015 2). Similarly, while Latvia currently retains a relatively high level of women's representation in parliament, more pro-active gender equality policies will prove necessary to promote any meaningful forms of substantive representation (Rastringa, 2015).

Both Latvia and Lithuania have relatively weak, decentralised women's movements with limited points of access to influence state policy. In an evaluation of Latvia's women's movement, Picukane finds that the movement is not widespread nor very influential in terms of changes achieved, and the cooperation among organisations involved in the movement is weak (Picukane, 2003, 1). Since accession, gender studies and women's organisations in Lithuania have become more prominent. Yet, Jurènienè finds 'Despite this advancement, it is not fashionable to be a feminist in Lithuania. Even women researchers interested in gender issues and involved in related studies usually do not identify themselves as feminists' (Jurèniené, 2015, 2). Although gender equality has become more of a priority in Lithuania, the influence of the women's movement proves low when compared to other countries of the EU but markedly similar to the situation in Latvia. Because of the similarities outlined above, Latvia and 
Reinvention: an International Journal of Undergraduate Research 13:1 (2020) Lithuania's shared communist history, as well as their political systems, overall gender equality, economic women's representation, women's movements can be discounted as significant explanations for the number of women in their respective parliaments.

\section{Literature review}

There are various schools of thought that can explain women's descriptive representation in post-Soviet parliamentary democracies. Some scholars maintain that the prevalence of women's organisations is the most significant factor influencing women's descriptive representation. Others argue that the commitment of political parties to promoting gender equality has the highest impact on increasing the number of women in office. However, the cases of Latvia and Lithuania demonstrate that, in the absence of a proportional representation (PR) system or a strong proportional tier in a mixed system, these explanations prove insufficient, particularly in the case of post-Soviet democracies. The critical difference between Latvia and Lithuania lies in their electoral systems - and electoral systems present the most compelling explanation for the current number of women in their respective parliaments.

The number of women holding elective office across parliamentary democracies has increased considerably in recent decades, and many scholars attribute this increase to the influence of women's interest groups or organisations. These groups, which often champion certain issues related to gender equality generally and women specifically, provide a point of access for women to gain political experience and enter decisionmaking positions (Francia, 2010, 151). Conversely, organisations in most Eastern European countries have largely failed to develop a unified, coherent agenda, suggesting that the presence of women's groups do not fully explain instances of high women's representation in newly democratic, post-Soviet countries such as Latvia (Sloat, 2005, 437). Unlike Latvia, Lithuania has a number of women's organisations that focus largely on providing services to women such as psychological, financial and legal help (Stankevicius. 2012, 58). Lithuania's Women's Parliamentarian Group is an organisation within the parliament that advocates for women's civil rights. However, because Lithuania has substantially fewer women in parliament than Latvia, the presence of women's organisations (particularly in the absence of strong proportional tier) does not have a sufficient causal relation to the number of women in office.

One of the most prevalent explanations for enhanced women's descriptive representation is the commitment of political parties to promoting gender equality and supplying women candidates. Evidence has shown that potential women 

candidates are subject to bias in recruitment that hinders the cause of electing more women to state legislatures and Congress because party chairs who are men consistently prefer candidates like themselves (Niven, 1998, 57). Effectively, party chairs who are men express a consistent preference for traits associated with themselves, 'a preference strong enough to affect their list of prospective legislative candidates', as Niven puts it $(1998,57)$. Therefore, political parties, to a large degree, determine who can and cannot succeed in the political arena. In Lithuania, some progressive political parties have demonstrated a trend toward greater gender parity in their recruitment processes by placing more women on party lists for seats in the proportional tier of the electoral system. The Farmers and Greens Union, which holds a plurality in parliament, successfully elected 11 women to parliament (the highest number of the parties with a seat share), and Lithuania's social democratic party has even adopted quotas. Nonetheless, although the Farmers and Greens Union, a progressive party that proved successful largely as a response to political corruption, contributed the highest number of women to parliament, only 20 per cent of the party's seat share is comprised of women (Lithuanian Republic Seimas, 2019). Moreover, the strategies that promote equality, specifically quotas, have proven ineffective due to 'a lack of solidarity among women parliamentarians...and disagreements among social democrats as the only party where gender quotas are laid down in its Statute' (Mejere, 2008, 54). Competition over seats in the favoured majoritarian tier of Lithuania's electoral system is largely what instigate these disagreements between social democrats seeking to maximise their party's vote (Mejere, 2008, 54). Conversely, women in Latvia have found significant electoral success in the absence of party quotas. The political parties' explanation for women's descriptive representation proves deficient in the cases of Latvia and Lithuania, and presumably, similar post-Soviet democracies.

Electoral systems play a decisive role in effecting the election of women to office and act as the most significant explanation for the number of women in Latvia and Lithuania's respective parliaments. Rule argues that electoral systems act as the most important factor in determining the success of women candidates, claiming that proportional representation (PR) systems are more beneficial to women running for office (Rule, 1994, 689). Studies have found that PR systems provide a substantial advantage over majoritarian/single-member district (SMD) systems because lists, and not specific candidates, are the focus of voting (Rule, 1994, 691). PR systems have higher rates of legislative turnover or higher district magnitude than majoritarian or 
Reinvention: an International Journal of Undergraduate Research 13:1 (2020)

SMD systems, which makes it easier for women to run for and win office because they are not competing as newcomers against incumbents (Rule 1994, 691).

Mixed systems, which consist of one proportional tier and one majoritarian tier, are often viewed as the 'best of both worlds', combining the multi-party inclusivity of the PR system with the individual agency of the SMD system. However, Raabe and Linhart (2016) assert that mixed electoral systems adversely affect proportional representation in newer democracies, such as Latvia and Lithuania. The authors' large $\mathrm{N}$ study demonstrates that the general conjecture of mixed electoral systems providing the 'best of both worlds' is not confirmed by empirical data. In contrast, the performance of mixed systems is largely affected by technical details as well as country-specific contexts (namely consolidated vs developing democracies). Mixed systems in newer democracies tend to favour the majoritarian pole, which hinders proportional representation (Raabe and Linhart, 2016, 21). This finding has important implications for women's representation in Lithuania's mixed system and further demonstrates that women's electoral success in Latvia can be attributed to its pure PR system. In a significant 2001 study, Moser argues against the notion that electoral systems meaningfully influence the electoral success of women candidates, in the context of post-communist democracies (Moser, 2001, 367). In a large-scale examination of electoral systems across post-communist states, with a particular focus on Russia, Moser finds that that SMDs are actually slightly more beneficial to some women candidates and more women are elected to these districts. Moser attributes this finding to:

Patriarchal attitudes and communist legacies [that] may make parties (and the centralization of nominations in party leadership under PR) a hindrance rather than an aid to women's representation in post-communist states. Conversely, the lack of institutionalization of party systems in post-communist states has meant that parties tend to play a less central role in nominating candidates and providing voting cues to the electorate.

- (Moser, 2001, 367)

However, more recent data in places such as Poland, the Czech Republic, Latvia and Lithuania suggests that electoral systems do play an important role. Moser's study uses data from before 2001, a largely corrupt and transitionary time for post-Soviet governments seeking to democratise. Therefore, new studies are needed to evaluate the role of electoral systems in the success of women candidate in post-Soviet countries. 


\section{Case studies}

As this study is concerned with the descriptive representation of women, I will be focusing on the 2018 and 2016 parliamentary elections results for Latvia and Lithuania. In order to prove the electoral systems explanation, I will begin by looking at the sheer number of women candidates and representatives elected in Latvia's proportional system and Lithuania's single-member and proportional tiers, focusing specifically on how the single-member tier undercuts the potential number of women in Lithuanian parliament. As a general point, the greater number of parties in PR systems provides an increased likelihood that one party will decide to promote women candidates (Matland and Studlar, 1996). Therefore, I will look at how political parties have structured their party lists, as well as the share of women parliamentarians in contrast to the number of women candidates nominated by parties Latvian and Lithuanian. The ideological makeup of these parties will also be considered. In terms of sources, I will primarily utilise databases, such as the Interparliamentary Union database, and official evaluations/reports on Latvian and Lithuanian political campaigns and election results. Moreover, because relatively little research has been done regarding the effects of electoral systems on equality in post-Soviet countries, in addition to the lack of publicly available election data, studies that examine such effects in similar cases will be applied to Latvia and Lithuania.

\section{Latvia}

Latvia's PR system has proven significantly conducive to the supply and election of women candidates. The percentage of women in the Latvian parliament has ebbed and flowed over the past decade (Interparliamentary Union, 2018). However, since the 2018 elections, women currently make up 31 per cent of Latvia's parliament, reaching the EU's standards for critical mass (Interparliamentary Union, 2018). This increase in women parliamentarians is rather remarkable considering that the Latvian government implements no quotas, Latvian women's organisations are virtually obsolete, and gender equality is relatively low on parties' agendas.

In the 2018 election, Latvia's dramatic shift from 19 per cent to 31 per cent of women parliamentarians, despite lacking institutional frameworks for promoting women candidates, indicates that the PR system plays a significant role in the election of women to parliament (Interparliamentary Union, 2018). To be sure, shifts in voter attitudes and dissatisfaction with current political leaders are possible factors 
contributing to this significant 12 per cent jump. However, crucially, the infrastructure of a PR system is more receptive to these normative shifts and changes in voter preferences than an SMD system. In a PR system, parties are held more accountable to the changing preferences of their core supporters. Moreover, less competition for seats in office due to high district magnitude, a product of the PR system, makes it considerably easier for parties to promote women candidates and for these candidates to be successful.

Parties' willingness to put forth women candidates in the PR system has undoubtedly affected women's representation in Latvia. Scholars generally agree that the greater number of parties in PR systems provides an increased likelihood that one party will decide to promote women candidates (Matland and Studlar, 1996). Latvia has an openlist PR system, which many argue is less beneficial to women than closed-list PR because parties have less control over the elective success of the candidates on their party lists. Interestingly, the open-list system has appeared to be beneficial to some women candidates in the case of Latvia. Kunovich (2003) finds that, in an open-list PR system, voters have the opportunity to engage in intra-party preference voting. Parties can indicate their preference for particular candidates by their placement on electoral lists (p. 273). The voters can then comply with the party's preferences and vote for the candidates in the top positions, or they can reject the party's preferences by voting further down the electoral list (p. 273). Subsequently, voters can shift the position of particular candidates on electoral lists. Kunovich examines the effects of open-list PR systems on gender equality in Poland and the Czech Republic. Like Latvia, both Poland and the Czech Republic have open-list PR systems with multimember districts. Her research suggests that, because major political parties in postcommunist countries typically view female candidates as less desirable than male candidates, an open-list system can allow voters to deviate from party preferences and elect more women to office (Kunovich, 2003, 290; 2012, 174). In a later study, Kunovich (2012) confirms that:

[there is no] systematic evidence that having an open-list system was an obstacle to women's election in Poland. In fact, I found that voters across the political spectrum positively shifted female candidates up the electoral list. Many parties often responded to positive shifts in the previous election by increasing the percentage of women in top positions on their subsequent lists. - (p. 174) 
Reinvention: an International Journal of Undergraduate Research 13:1 (2020)

This implication proves especially important in the case of Latvia where women have been well-incorporated into the economic sphere and a large portion of voters is comprised of women.

Although Kunovich examines Poland and the Czech Republic in her studies, her findings - specifically in terms of the relationship between a post-communist openlist system and higher women's descriptive representation - can be applied to the Latvian case. Parties in Latvia have nominated significant numbers of women, not to push women's issues, but to emphasise these women as 'competent technocrats and as less corrupt than the average Latvian politician' (Matland and Lilliefeldt, 2014). It also appears that voters in Latvia are largely indifferent to candidate gender but, with a party hierarchy that tends to hold women back, preferential voting in the Latvian PR system has, in several cases, helped women, particularly in the most recent election where women candidates may have been seen as reflective of positive change (Matland and Lilliefeldt, 2014). Comparing the share of women candidates to the share of women in parliament, 31 per cent of Latvia's candidates were women, and 31 per cent of Latvia's current parliament is comprised of women - a largely unprecedented ratio of success for women's representation before and after an election. The electoral success of opposition parties, namely KPV and Harmony, indicates that the change in Latvians' voter preferences, which reflects an ideological shift away from the outgoing parliament's position, duly coincides with the election of more women candidates (Latvia Central Election Commission, 2018). Commenting on the Latvian election results, Ekmanis writes, 'the desire for fresh perspectives is in votes for newer parties and more female representation' (Ekmanis, 2018). Latvia's recent election saw a surge in success of women newcomers and, in some cases, women were even reranked by voters to be closer to the top of the party list (Latvia Central Election Commission, 2018). For instance, Janina Kursite was ranked tenth for the Latgale region on the KPV party's list but was moved to the first rank in order to successfully gain a seat in the new parliament (Latvia Central Election Commission 2018). In the Vidzeme region, Karina Sprude was originally ranked ninth but moved to the third rank, and Attīstībai/Par!'s Inese Ikstena was moved from tenth to third to comply with voters' preferences (Latvia Central Election Commission, 2018). According to the candidate lists of parties with a seat share in the current parliament, before and after preferential voting, approximately 38 per cent of elected women were reranked to be higher on the list. If women were not reranked to a higher spot, most retained the same rank they had prior to preferential voting. 
Permitted by the multi-polarity distinctive to the PR system, opposition parties were able to make a significant mark in Latvia's most recent election. In their article, Matland and Studlar (1996) seek to explain gaps in women's representation across electorates, arguing that traditional parties will feel pressured to nominate more women if one of their political rivals starts to promote representation of women. Crucially, opposition or fringe parties consistently promote more women candidates on their party lists (Matland and Studlar, 1996). In terms of the Latvia case, a PR system has allowed for the electoral success of alternative parties. Although the electoral success of women was similar across parties, with each successful party supplying an average of four elected women, the opposition parties with a seat share in the current parliament, such as the KPV and Attīstībai/Par! tended to promote more women candidates than the major parties, specifically New Unity, which had been a leading party in Latvia since 2010 (Latvia Central Election Commission, 2018). New Unity now possesses eight seats in parliament, only one of which is held by a woman (Latvia Central Election Commission, 2018). Because opposition parties had women ranked higher on their lists, whether through preferential voting or an unchanged ranking, their electoral success evidently led to an increased number of women in parliament, enhancing women's descriptive representation.

\section{Lithuania}

Despite having a variety of women's organisations and quota adoption on the partylevel, Lithuania's 2016 election results showed that women retained 21 per cent of seats in parliament, which is 2 per cent below the world average and nearly 10 per cent below EU standards (Interparliamentary Union, 2016). It is important to note that women's share of seats in the Lithuanian parliament shifted to 24 per cent in October 2019. However, due to a lack of available election data and the low statistical significance of the shift, this paper will focus on Lithuania's previous election. As more information on party-list configurations and voting patterns for the 2019 election become available, the validity of this thesis will require further evaluation. In Lithuania, with a fluctuation of 19-24 per cent women elected to parliament over the past four election cycles, party competition tends to focus on the SMD tier of the mixed system, suggesting that with a stronger proportional tier or pure PR system, the Lithuanian parliament would have a higher percentage of women in parliament (Jastramskis 2018, 1; Interparliamentary Union, 2018). This finding is consistent with the argument that SMDs are unfavourable for the representation of women and 

explains why Lithuania has such a low number of female representatives, even with the presence of women's organisations.

Before further discussion of Lithuania's electoral system, it is necessary to note that Lithuania is a predominantly Catholic country while Latvia is not. In this vein, one could argue that religion is a more significant factor than the electoral system in contributing to voter and party preferences, which in turn affects the number of women elected to parliament. The stratification of religious messages across major parties is not widespread enough to support this claim. Lithuania's Christian Democratic party and the Electoral Action of Poles are strong advocates of Catholic values, although to different ends - the latter is pro-Kremlin while the former is not (Jurkynus, 2016, 47). However, in the 2016 election, Lithuanian Farmers and Green Union achieved a landslide victory (38 per cent seat share in parliament) on a largely secular platform that focused on environmental and agrarian issues (Jurkynus, 2016, 49). The party formed a coalition with the small faction of the Social Democrats, the party with the third-highest number of seat shares and the only party to implement quotas for women's representation (Jurkynus, 49, 2016). This suggests that, in the 2016 election, religion did not play a major role in dictating voter preferences and therefore did not necessarily contribute to the low total of women in Lithuania's parliament. More than half of the few women in the Lithuanian Farmers and Green Union were elected in multi-member districts (Central Electoral Commission of the Republic of Lithuania). Interestingly, in the 2019 elections, the Christian Democratic party assumed the majority in parliament and women's representation went up by 3 per cent, while the Lithuanian Farmers and Green Union still maintained a high seat share (Lithuanian Republic Seimas, 2019). This further demonstrates that underlying traditionalist attitudes and Catholic voter preferences do not have a substantial effect on the number of woman parliamentarians in Lithuania and subsequently highlights the structure of the country's PR-SMD electoral system as a distinctive factor.

The Lithuanian case demonstrates how the strength of the SMD tier considerably affects the success of women candidates. Mixed systems, combining the multi-party inclusivity of the PR system with the individual agency of the SMD system, are sometimes referred to as 'the best of both worlds'. The basic argument for mixed systems is that candidates allocate their campaign and legislative efforts between representing organised and unorganised interests (Kerevel, 2010, 2). The author writes: 
Reinvention: an International Journal of Undergraduate Research 13:1 (2020) organized interests, or interest groups, provide resources that aid in a candidate's reelection, while unorganized interests, or ordinary citizens provide the votes needed to win an election. The reasoning is that the needed votes to win an election are primarily the result of the activities of SMD candidates, while PR candidates have little individual incentive to allocate their effort towards maximising the vote.

- (Kerevel, 2010, 2)

As a result, parties tend to favour the majoritarian tier in order to obtain a plurality in parliament and promote popular incumbents, who are often men, rather than new women candidates (Kerevel, 2010, 3). As Kerevel and previous studies suggest, incumbents, which are usually men, are likely to be reelected in the SMD tier. Because SMDs only return a single officeholder to the legislature, elections in the SMD tier are significantly more competitive and, as a result, parties are less likely to risk losing votes by promoting women newcomers. In Lithuania's mixed system, 71 members are elected using majoritarian rules in the SMD tier and 70 members of parliament are elected using proportional representation (Jurkynus, 2016, 47). Although members of parliament elected through the SMD tier hold a slightly higher seat share, women only make up approximately 37 per cent of party nominees in this tier (Central Electoral Commission of the Republic of Lithuania).

The Christian Families Alliance and the Political Party 'List of Lithuania' fielded the highest numbers of women candidates, 51 per cent and 48 per cent respectively, and included the highest numbers of women candidates in winnable positions (Office for Democratic Institutions and Human Rights, 2017, 10). However, the 'List of Lithuania' elected no members and the Christian Families Alliance was only able to elect three women, two of whom were elected by party list (Lithuanian Republic Seimas, 2019). Of the women elected to Lithuania's parliament, approximately 61 per cent were elected from multi-member districts (Lithuanian Republic Seimas, 2019). In this vein, the mixed design of the electoral system and specifically its SMD tier undercuts the potential number of women in the Lithuanian parliament.

Lithuania's SMD tier has also largely restricted the influence of institutions designed to promote women candidates due to the low district magnitude that characterises majoritarian systems. In many Eastern European countries, high competition for a low number of seats between women politicians in a majoritarian system or tier has adversely affected the influence of women's organisations on increasing representation (Sloat, 2005, 437). For instance, the founder of Lithuania's Women's 
Parliamentarian Group, Birute Vesaite, established the group to improve women's rights in Lithuania, but many other parliamentarians interpret this action as a competitive attempt to be reelected (Stankevicius, 2012, 59). Because the Lithuanian system favours the majoritarian tier over the proportional tier, women candidates are often positioned as divergent rivals competing for a limited number of seats, which has yielded negative consequences not only for women's substantive interests but also for the widespread promotion of women candidates. Importantly, in the Lithuanian political system, political organisations and interest groups cannot put forward candidates for election in the single-member or multi-member electoral districts (Taljunaite, 2004, 2). Effectively, Lithuania's mixed system limits the influence of institutional measures that seek to promote minority interests.

\section{Conclusion}

Latvia and Lithuania demonstrate that proportional representation electoral systems are overall more favourable to women candidates than mixed systems and provide evidence that electoral systems are a significant explanation for women's electoral success in the post-Soviet space. Latvia's PR system has proven conducive to the election of women candidates, even in the absence of women's groups and quotas. In this vein, if women's organisations and political parties in the Latvian parliament were to institutionalise gender equality, the success of women candidates in the country could prove monumental. Conversely, in the absence of a strong proportional tier, Lithuania's women's organisations and progressive parties have limited influence on women's representation in parliament, and the SMD tier's low district magnitude makes it harder for women to get elected. As post-Soviet countries deeply entrenched in the legacy of communism, Latvia and Lithuania have strived to adequately accede to EU standards of equality. As a result, overcoming gender inequity and promoting women representatives has proven especially difficult for these countries.

Based on the available data, the cases of Latvia and Lithuania strongly suggest that transitioning to a more inclusive electoral system with a higher district magnitude may be the first and most crucial step to increasing women's descriptive representation in post-Soviet democracies. However, a significant limitation of this project was the lack of publicly available election data, especially in terms of Lithuania's most recent election. The electoral commissions in both countries do not provide information on voting patterns and demographics that include factors such as age, profession, or religion. Widely used, reputable platforms, such as the World Bank and the Interparliamentary Union database, provide slightly conflicting election data 
for these countries. If data becomes available and accessible, more research on this topic will need to be conducted to demonstrate the cogency of the electoral systems explanation for women's descriptive representation in Latvia and Lithuania. Although Latvia's PR system provides an explanation for the electoral success of women in response to changing voter preferences, more research into why these preferences changed and voting patterns shifted away from the established parties is needed.

\section{Acknowledgements}

I thank my adviser on this project, Dr Alisa Gaunder, for her invaluable guidance and encouragement.

\section{References}

Avdeyeva, O. (2010), 'States' compliance with international requirements', Political Research Quarterly, 63 (1), 203-17

The Central Electoral Commission of the Republic of Lithuania (2016). The Elections to the Seimas, held on 9 October 2016, available at https://www.vrk.lt/en/pagaldata, accessed 3 April, 2020

Ekmanis, I. (2018), 'Latvia's Elections: The view from afar. Eurasia bulletin, Foreign Policy Research Institute', available at https://www.fpri.org/article/2018/10/latviaselections-the-view-from-afar/, accessed 27 March 2019.

European Institute for Gender Equality.(2017),Gender Equality Index 2017: Latvia, available at https://eige.europa.eu/publications/gender-equality-index-2017-latvia, accessed 27 March 2019.

European Institute for Gender Equality. (2017), Gender Equality Index 2017:

Lithuania, available at https://eige.europa.eu/publications/gender-equality-index2017-lithuania, accessed 21 March 2019.

Francia, P.. (2010), 'Women's Organizations as Leaders in Finding and Supporting Female Candidates', in O'Connor, K. (ed.), Gender and Women's Leadership: A Reference Handbook, Thousand Oaks, CA: Sage Publications, pp. 151-59

Interparliamentary Union. (2018), Latvia and Lithuania, available at https://www.ipu.org/", accessed 20 March 2019. 
Jastramskis, M. (2018), 'Effects of mixed parallel electoral system in Lithuania: The worst of both worlds?', Parliamentary Affairs 30, 1-27

Jurkynus, M. (2017), The parliamentary election in Lithuania, October 2016, Electoral Studies 47, 46-50.

Jurėnienė, V. (2015), 'Gender roles in Lithuanian Society', Global Journal of Human Social Science, $10(6), 2-7$

Kerevel, Y. (2010), 'The legislative consequences of Mexico's mixed-member electoral system, 2000-2009', Electoral Studies 30, 1-13.

Kunovich, S. (2012), 'Unexpected winners: The significance of an open-list system on women's representation in Poland', Politics \& Gender 8, 153-177

Kunovich, S. (2003), 'The representation of Polish and Czech women in national politics: Predicting electoral list position', Comparative Politics 35 (3), 273-291

Latvia Central Election Commission. (2018), Saeima Elections, available at https://sv2018.cvk.lv/pub/ElectionResults, accessed 20 May 2019. Translated via Google Translate.

Lithuanian Republic Seimas. (2019), Political Groups in the Seimas, available at https://www.lrs.lt/sip/portal.show?p_r=8956\&p_k=2, accessed 16 June 2019. Translated via Google Translate.

Matland, R. and E. Lilliefeldt. (2014), 'The effect of preferential voting on women's representation', in Escobar-Lemmon, M., (ed.), Representation: The Case of Women, London: Oxford University Press

Matland, R. E. and D. Studlar, (1996), 'The contagion of women candidates in singlemember district and proportional representation electoral systems: Canada and Norway', Journal of Politics, 58 (3), 707-33

Mejere, O. (2012), 'Does gender matter in governance? Gender quotas as a good policy tool: Practice and failures in Lithuania', Socialiniai Tyrimai, 27 (2), 46-61

Moser, R. (2001), 'The effects of electoral systems on women's representation in postcommunist states', Electoral Studies 20, 353-69. 
Niven, D. (1998), 'Party elites and women candidates: The shape of bias', Women and Politics, 19 (2), 57-80.

Office for Democratic Institutions and Human Rights.(2017),'Republic of Lithuania Parliamentary Elections 9 October 2016: OSCE/ODIHR Election Assessment Mission Final Report', , available at

https://www.osce.org/odihr/elections/lithuania/296446?download=true, accessed 17 June 2019.

Picukane, E. (2003), 'Why is there no women's movement in Latvia?', Presented at Gender and Power in the New Europe, the 5th European Feminist Research Conference August 20-24, 2003 Lund University, Sweden.

Raabe, J, and E. Linhart. (2016), 'Mixed member proportional electoral systems - The best of both worlds?', Journal of Elections, Public Opinion and Parties, 29, 21-40.

Rastringa, O. (2015), 'The policy on gender equality in Latvia', Citizens Rights and Constitutional Affairs Report: Gender Equality. European Parliament.

Rule, W. (1994), 'Women's underrepresentation and electoral systems', Political Science and Politics, 27 (4), 689-692.

Stankevicius, S. (2012), 'Lithuanian women in the parliament: Access and participation in postSocialist politics', Thesis Dissertation. The Institutional Repository at DePaul University, available at https://via.library.depaul.edu/cgi/viewcontent.cgi? referer=https://www.google.com/ttpsredir=1 \&article $=1118$ \&context=etd, accessed 3 April 2019.

Sloat, A. (2005), 'The rebirth of civil society', European Journal of Women's Studies 12 (4), 437-52.

Taljunaite, M. (2004), 'The women's movement in Lithuania: Discourses and lobbying strategies', International Institute for Democracy and Electoral Assistance (IDEA)/CEE Network for Gender Issues Conference, Budapest, Hungary, 22-23 October 2004.

Tripp, A. (2013), 'Political systems and gender', in Waylen, G., K. Celis, J. Kantola and S. Laurel Weldon, (eds), The Oxford Handbook of Gender and Politics, Oxford: Oxford University Press, pp. 514-535 


\section{Glossary}

Proportional representation electoral system In a proportional representation (PR) system, parties, rather than individual candidates, gain seats in proportion the number of votes cast for them. Parties will rank their candidates on a list and constituents will vote to elect the party list. PR systems tend to have a high district magnitude, which means there are more seats to be held.

Majoritarian or Single-Member District systems In a majoritarian electoral system, also referred to as single-member district (SMD) systems, constituents vote for an individual rather than the party and return a single officeholder to the legislature. Subsequently, elections in SMDs are often more competitive between candidates because there is only one seat to be held.

Mixed system A mixed system consists of both a majoritarian/single-member district tier and a proportional representation tier. The number of seats allocated for each tier varies across mixed systems.

Unicameral parliamentary system A unicameral parliamentary system is a parliament with one legislative chamber.

To cite this paper please use the following details: Beam, A. (2020), 'Women's Representation in the Post-Soviet Space: Latvia and Lithuania', Reinvention: an International Journal of Undergraduate Research, Volume 13, Issue 1, https://reinventionjournal.org/article/view/559. Date accessed [insert date]. If you cite this article or use it in any teaching or other related activities please let us know by emailing us at Reinventionjournal@warwick.ac.uk. 